Рекомендована д. біол. наук, профр. Л. С. Фірою

УДК 581.4:582.794.1

\title{
МОРФОЛОГО-АНАТОМІЧНЕ ДОСЛІДЖЕННЯ БЕДРИНЦЮ ЛОМИКАМЕНЕВОГО (PIMPINELLA SAXIFRAGA L.)
}

\author{
(С). М. Марчишин, Т. М. Гонтова, Е. А. Панасюк \\ Тернопільський державний медичний університет імені І. Я. Горбачевського \\ Національний фрармацевтичний університет, Харків
}

Резюме: проведено морфолого-анатомічне дослідження трави та кореневищ бедринцю ломикаменевого. Для ідентифрікації сировини встановлено основні макро- і мікроскопічні ознаки.

Ключові слова: бедринець ломикаменевий, трава, кореневища, макро- і мікроскопічні ознаки.

Вступ. Бедринець ломикаменевий (Pimpinella saxifraga L.) - багаторічна трав'яниста гола або короткоопушена рослина з родини селерові (Аріасеае) з прямими, розгалуженими, тонкоребристими стеблами 3 виповненою серцевиною, заввишки 30-60 см. Кореневище багатоголове, гіллясте. Прикореневі і нижні стеблові листки довгочерешкові перисторозсічені або перисті, серединні стеблові - перистороздільні, верхні - у вигляді піхов, без пластинок. Квітки дрібні, білі, п'ятипелюсткові, зібрані в складні багатопроменеві зонтичні суцвіття. Плоди - дрібні яйцеподібні двосім'янки. Росте розсіяно на схилах, трав'янистих горбах, на лісових галявинах, серед чагарників, уздовж доріг по всій території України. Цвіте 3 червня по серпень $[1,2,5,6]$.

3 давніх-давен бедринець ломикаменевий використовували у народній медицині як спазмолітичний, протизапальний, сечогінний, відхаркувальний, протикашльовий, фотосенсибілізуючий засіб [3].

Рослина $€$ офріцинальною в німецькій і швейцарської медицині; в Україні - неофіцинальна. Бедринець ломикаменевий $є$ недостатньо вивченою рослиною, тому вважаємо доцільним провести морфологоанатомічне і фрітохімічне дослідження.

Мета нашої роботи - провести макро- і мікроскопічний аналіз трави та кореневищ бедринцю ломикаменевого. Сировину заготовляли на трав'янистих пагорбах і схилах у Гусятинському районі Тернопільської області у 2014 році (траву - у липні-серпні, кореневища - восени після відмирання надземної частини рослини).

Методи дослідження. Для вивчення морфологічної будови сировини використовували лупу та бінокулярний мікроскоп МБС-9. При мікроскопічному дослідженні для вивчення анатомічної будови бедринцю готували мікропрепарати зі свіжозібраної та фріксованої в суміші 96 \% етанол - гліцерин - вода очищена (1: $1: 1)$ сировини [4, 7]. Діагностичні мікроскопічні ознаки фріксували за допомогою мікроскопу «Granum» при збільшенні ×40, ×100, ×400 разів.
Фотознімки робили за допомогою фотоапарату Sony DSC-W80.

Результати й обговорення.

Макроскопічні ознаки кореневища бедринцю ломикаменевого

Веретеноподібні, поздовжньо-зморшкуваті кореневища до 5 см завдовжки, товщиною від 2 до 5 мм. Зовні сірувато-бурого кольору, злам нерівний, жовтувато-білого кольору з жовто-бурими крапками. Запах сильний, ароматний, подразнюючий. Смак гострий, солодкувато-гіркий.

Мікроскопічні ознаки кореневища бедринцю ломикаменевого

Кореневище. Кореневище вкрите товстим шаром перидерми (рис. 1, 1). Корова паренхіма добре розвинена, складається з великих паренхімних клітин, що підстеляють покривну тканину і нижче розташовані дрібні клітини - елементи фрлоеми. Шар фрлоеми добре виражений, при додаванні розчину Люголя фрлоемна паренхіма забарвлюється у темно-синій колір, що доводить накопичення крохмалю (рис. 1, 2). Флоема розділяється рівномірно широкими серцевинними променями. У верхній частині корової паренхіми містяться видовжені повітряні порожнини. У коровій паренхімі зустрічаються чисельні невеликі схизогенні вмістища округлої фрорми (рис. 1, 2), паренхімні клітини, що оточують їх, містять крохмаль. Центральний циліндр чітко відокремлений шаром камбію (рис. 1, 3). Судини розташовуються видовженими ланцюжками. Деревинна паренхіма накопичує крохмаль. У центрі кореневища чітко виражена порожнина.

Макроскопічні ознаки трави бедринцю ломикаменевого

Стебла тонкоребристі, розгалужені, короткоопушені. Листки перисті, довгочерешкові, край зубчастопилчастий. Квітки дрібні, п'ятипелюсткові, зібрані в складні зонтичні суцвіття. Плоди - дрібні яйцеподібні двосім'янки. Листкова пластинка зверху зелена, знизу - світло-зелена, квітки білі. Запах слабкий, приємний. Смак пряний, гіркуватий.

ISSN 2312-0967. Pharmaceutical review. 2015. № 2 

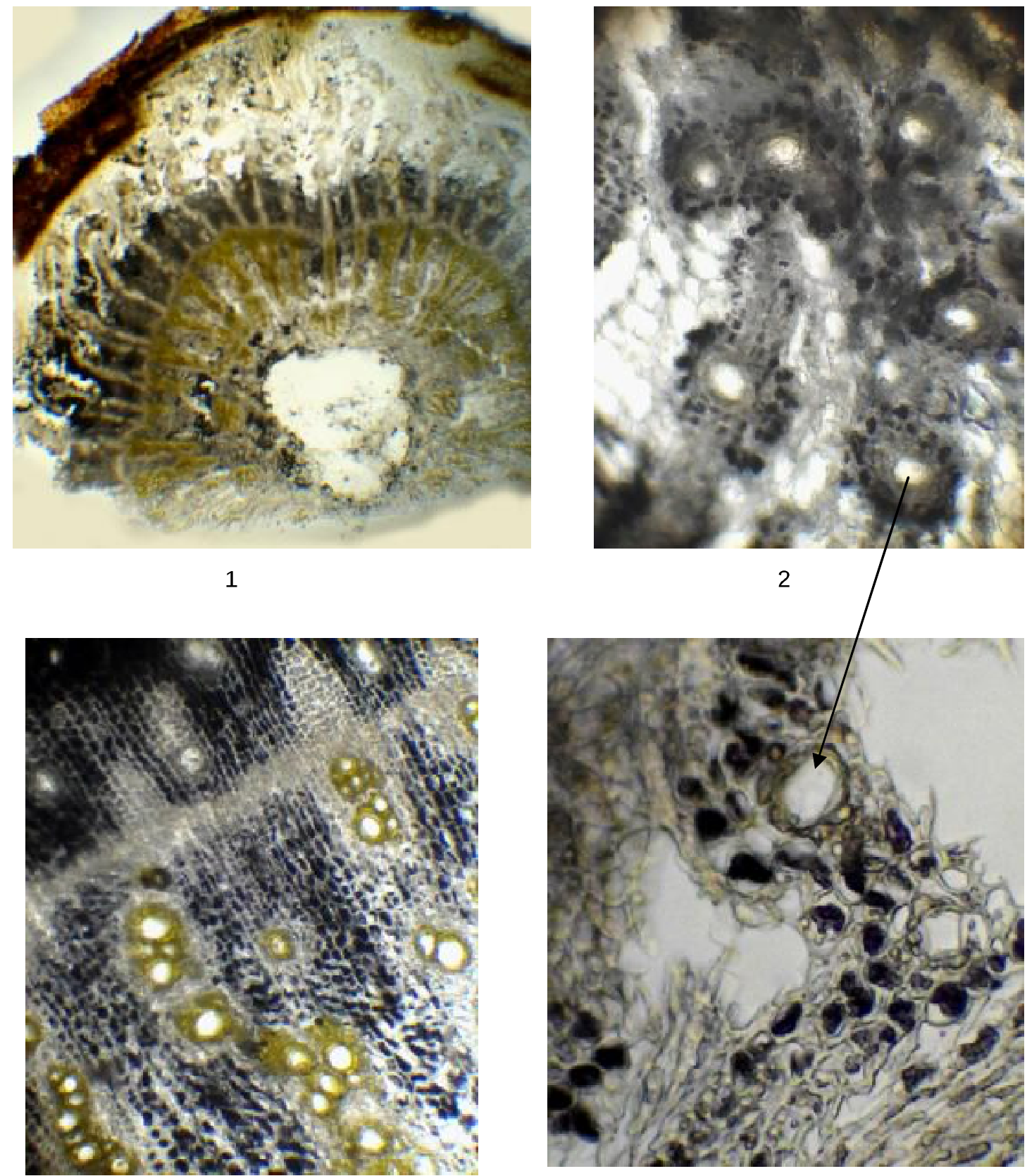

3

Рис. 1. Кореневище бедринцю: 1 - загальний вид, 2 - запасаюча корова паренхіма зі схізогенними вмістищами, 3 - фррагмент центрального циліндру.

\section{Мікроскопічний аналіз трави бедринцю ломи- каменевого}

Стебло на поперечному розрізі у верхній (рис. 2, 1) та середній частині багаторебристе, з округлими широкими 8 ребрами, у нижній частині ребристість майже невиражена (рис. 2, 3). Епідерма стебла дрібноклітинна, оболонки клітин прямостінні, слабко потовщені (рис. 3, 1, 3, 2). Продихи овальні, великі, нечасті. Продиховий апарат аномоцитного та анізоцитного типів (рис. 3, 2 a, б). Епідерма опушена нерівномірно.
У верхній частині стебла опушені значно менше, ніж у середній і нижній. Трихоми розташовуються поодиноко між ребрами і групами по ребрах (рис. 3, 1, 3, 3, а-в, 2, 1, 2, 3). Криючі трихоми довгі, зігнуті, багатоклітинні 3 невеликою базальною клітиною і видовженими основними клітинами (рис. 3, а), конічні 2-клітинні короткі (рис. 3, б), довгі 3-клітинні прямостоячі з видовженою апікальною клітиною (рис. 3, в).

Анатомічна будова стебла у нижній, середній та верхній частинах стебла перехідного типу (рис. 2, 1,

ISSN 2312-0967. Фармацевтичний часопис. 2015. № 2 
Фітохімічні дослідження

Phytochemical researches

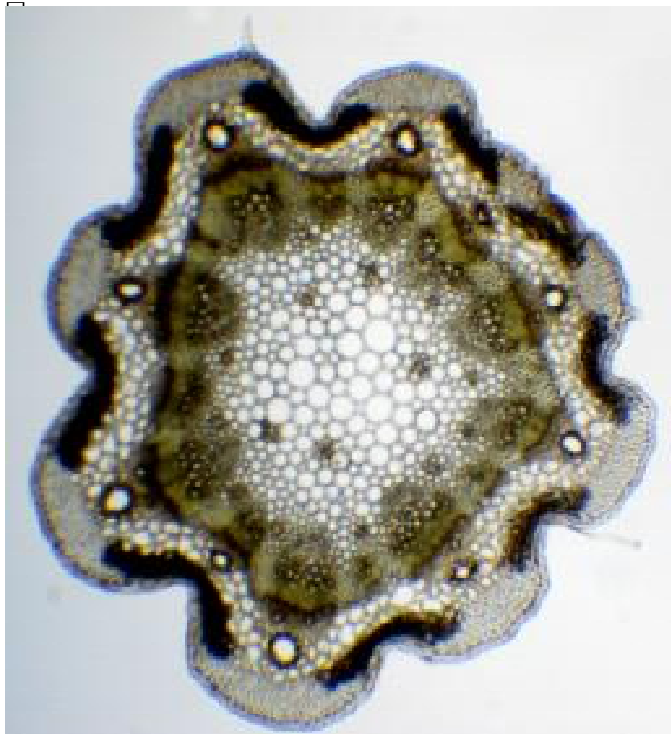

1

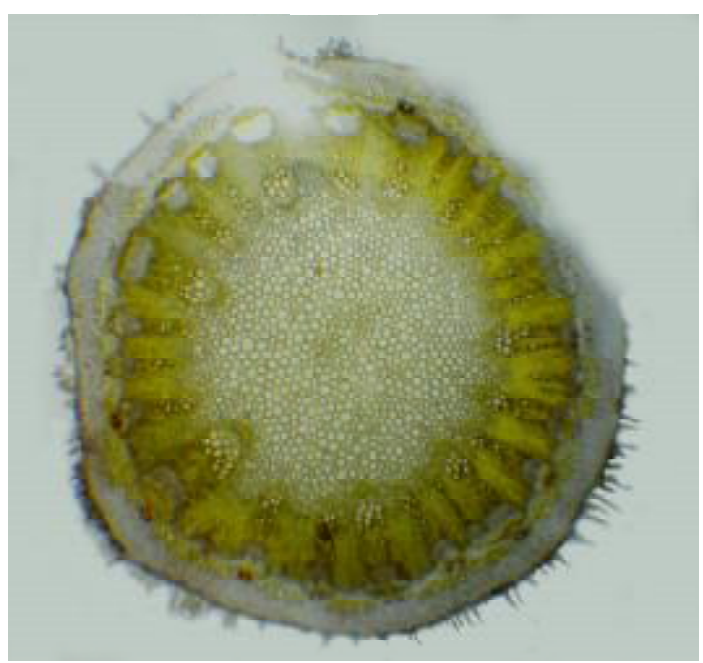

3

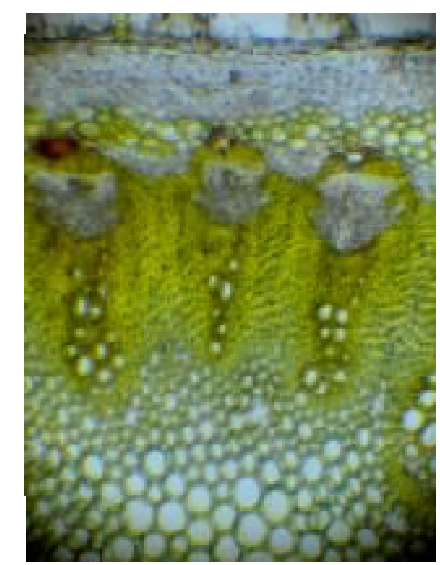

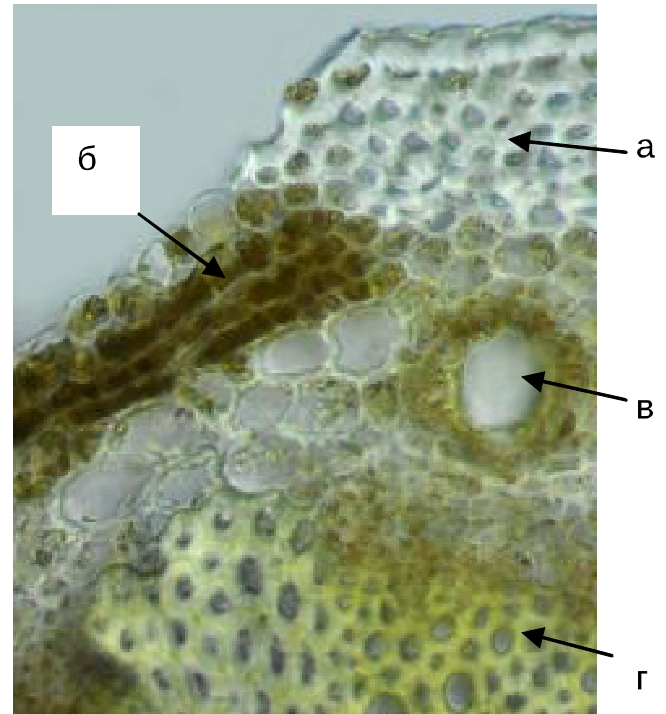

2

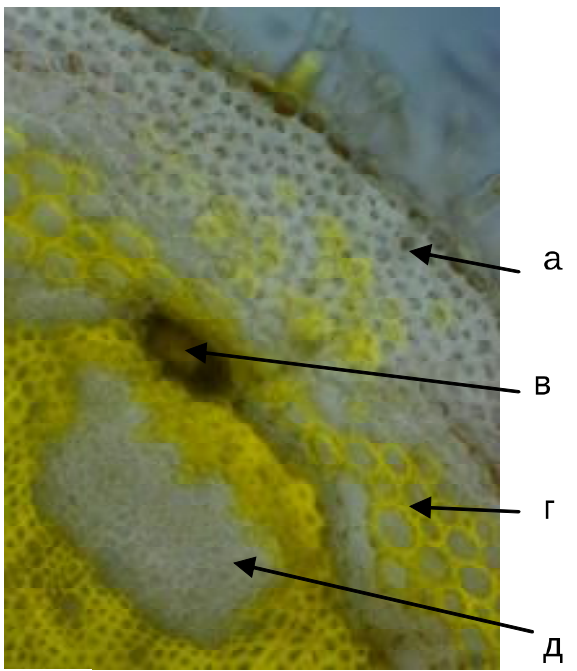

4

6

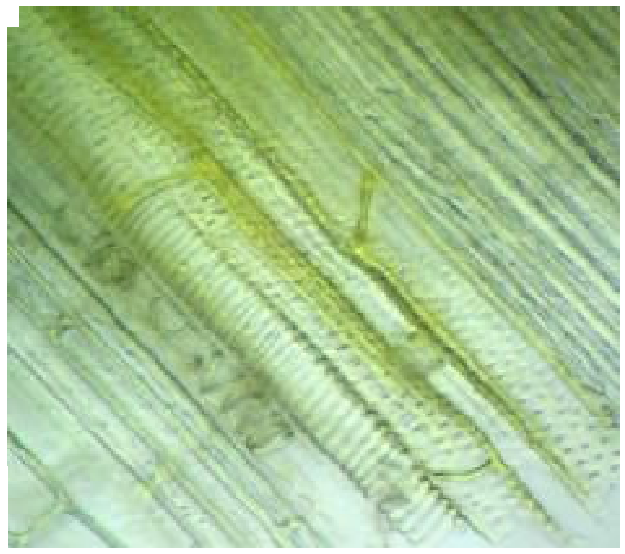

Рис. 2. Стебло бедринцю: 1 - верхня частина, 2 - фрагмент корової паренхіма (а - кутова коленхіма, б - хлоренхіма, в - схізогенне вмістище, г - склеренхіма), 3 - нижня частина, 4 - фррагмент центрального циліндру (а - кутова коленхіма, в - схізогенне вмістище, г - склеренхіма, д - фллоема), 5 - нижня частина, 6 - кільчасті, спіральні, пористі судини.

ISSN 2312-0967. Pharmaceutical review. 2015. № 2 


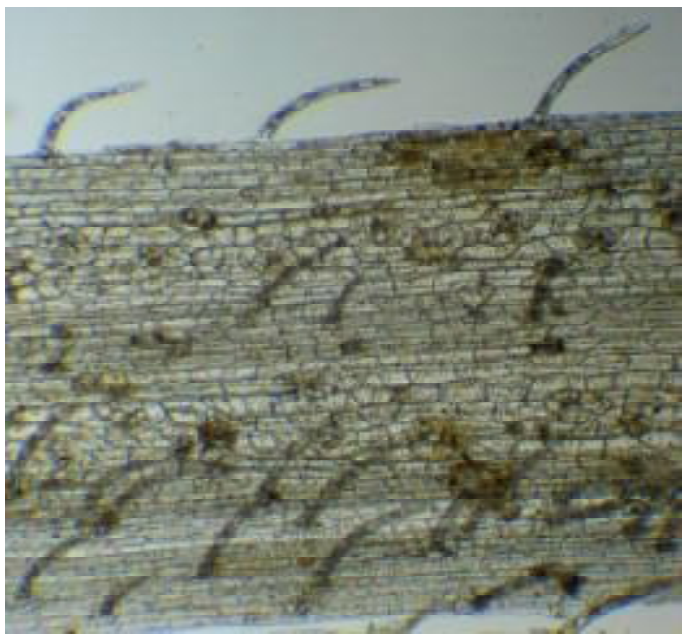

1

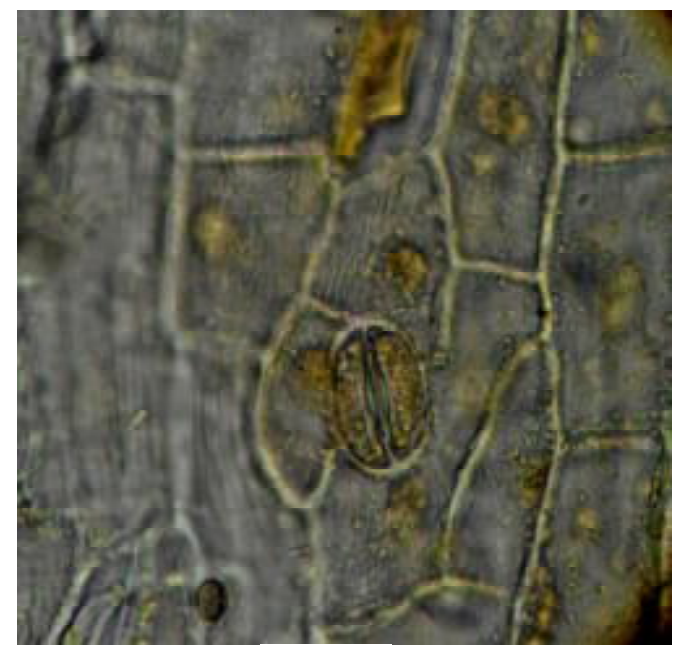

$2 \mathrm{a}$

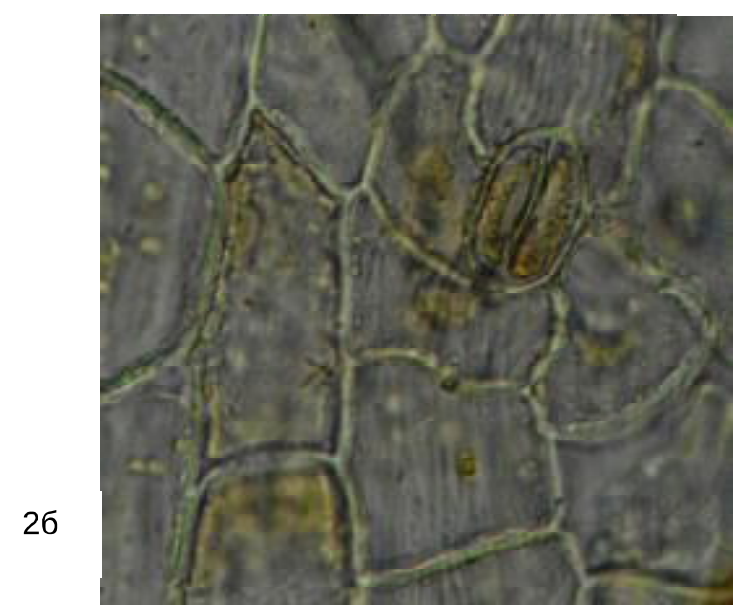

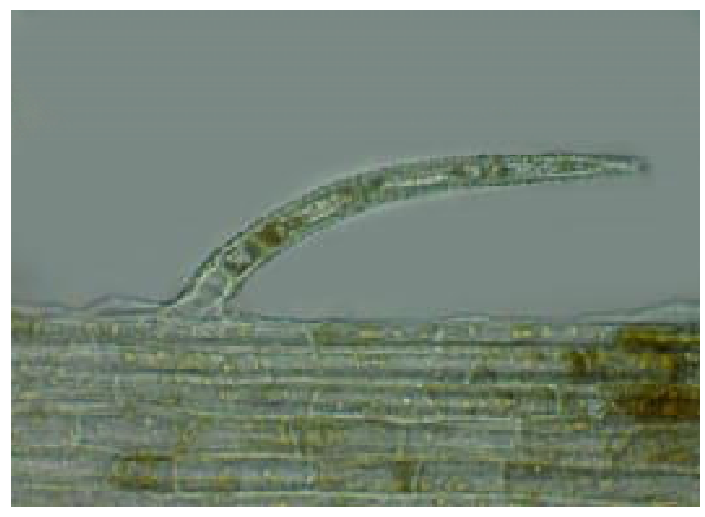

3

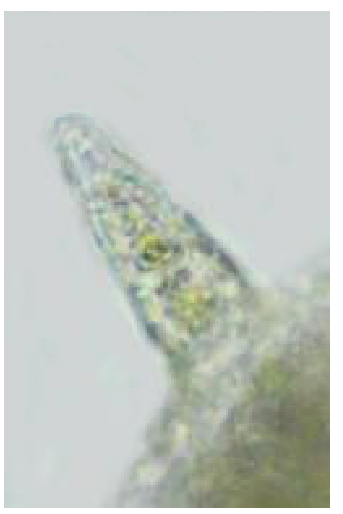

б

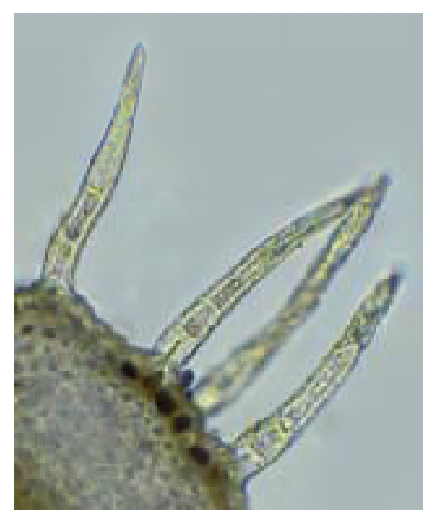

Рис. 3. Епідерма стебла бедринцю: 1 - загальний вигляд, 2 - тип продихового апарату: а - анізоцитний, б - аномоцитний, 3 - трихоми: а - довгий багатоклітинний волосок, б - 2-клітинний короткий волосок, в - 3-клітинний волосок.

2, 3). У верхній частині епідерму підстеляє добре виражений шар кутової коленхіми (рис. 2, 2 а). Між ділянками коленхіми розташовується 3-4 шари хлоренхіми (рис. 2, 2 б). Нижче розташована 1-2-шарова корова паренхіма, клітини якої великі, тонкостінні. Ендодерма виражена. У коровій паренхімі навпроти ребер розташовані схізогенні вмістища округлої фрорми (рис. 2, 1, 2 в). Основні судинно-провідні пучки

ISSN 2312-0967. Фармацевтичний часопис. 2015. № 2 
овальні майже однакові за фрормою, між ними містяться дрібні вузькі пучки ( рис. 2, 1). Флоема дрібноклітинна, шар камбію виражений, тонкий, у ксилемі переважає склерефіковані клітини лібрифрорму, що щільним шаром підстиляють клітини камбію. Судини ксилеми широко просвіті, нечисельні, розташовані безпорядно, за типом кільчасті, спіральні, пористі (рис. 2, 1, 2, 6). Серцевинні промені широкі, оболонки клітин склерефіковані. Перимедулярна зона представлена паренхімними невеликими клітинами, з тонкими оболонками. Серцевина складається 3 паренхімних клітин різного розміру.

Анатомічна будова стебла у нижній частині (рис. 2, 3) відрізняється за кількома ознаками: епідерма більше опушена, коленхіма кутовопластинчаста (рис. 2, 4 a), оболонки клітин коленхіми та корової паренхіми частково склерефікуються (рис. 2, 4 г), схізогенні вмістища мають видовжену фрорму (рис. 2, 4 в), фрлоема добре розвинена і закладається широкою ділянкою (рис. 2, 4 d), судини ксилема широкопросвіті, більш виражені, розташовуються ланцюжками, склерифікація клітин серцевинних променів більш виражена, під провідними пучками також виражений шар склеренхіми, серцевина добре виражена, клітини більш-менш однакового діаметра.

Листок дорзивентрального типу будови (рис. 4, 2). Палісадний мезофріл 2-рядний, губчастий - 4-рядний. Клітини палісадного мезофрілу невеликі, слабко виражені, за фрормою циліндричні або овальні, клітини другого внутрішнього шару розташовані нещільно. Клітини губчастого мезофілу дрібні, округлі або видовжені горизонтально. Продихи на нижній епідермі виступаючі (рис. 4, 2 а). Головна жилка округла зі слабко виступаючою верхньою частиною і значно виступаючою нижньою (рис. 4, 1). Епідерму підстеляє шар добре розвиненої кутової коленхіми. У центрі головної жилки міститься великий провідний пучок овальної фрорми. 3 обох боків провідного пучка фрло- ему і ксилему оточує склеренхіма. Клітини паренхіми середні за розмірами.

Верхня епідерма представлена паренхімними клітинами різної фрорми - від багатокутових до ізодіаметричної орорми (рис. 4, 3). Оболонки клітин слабко, чоткоподібно потовщені, з вираженими прямими порами. Між жилками клітини мають центричне розташування, ближче до жилки вони витягнуті, орієнтування вздовж жилок. Клітини нижньої епідерми над жилками (рис. 4, 4) витягнуті, прямостінні, 3 потовщеним оболонками. Між жилками клітини паренхімні, тонкостінні, з сильно звивистими оболонками (рис. 4, 5). Продихів багато, вони великі, овальної форми. Тип продихового апарату парацитний і аномоцитний.

Листок опушений нерівномірно (рис. 4, 2, 6). Більше трихом 3 нижнього боку, вони розташовані, в основному, групами вздовж жилок. За типом трихоми криючі 1-6-клітинні, товстостінні, бородавчасті, із закругленими верхівками.

Верхня епідерма пелюсток представлена паренхімними звивистостінними клітинами (рис. 5, 1) 3 сосочкоподібними виростами конічної фрорми (рис. 5, 2). На верхівках сосочків слабко виділяється складчаста кутикула. Клітини нижньої епідерми паренхімні, зі слабко звивистими тонкими оболонками, 3 великою кількістю продихів парацитного і аномоцитного типу (рис. 5, 3). Нижня епідерма вкрита шаром складчастої кутикули (рис. 5, 4). На верхній і нижній епідермі рідко зустрічаються криючі 1-3-клітинні трихоми з загостреними верхівками (рис. 5, 5 a, б). Пилок видовженої форми, з потовщеною оболонкою, за фрормою нагадує цифрру 8.

Висновки. Вивчено морфолого-анатомічні ознаки бедринцю ломикаменевого та визначено основні макро- та мікроскопічні діагностичні ознаки кореневищ, стебел, квіток та листків, які будуть використані при стандартизації лікарської сировини - розробки МКЯ «Бедринцю трава» та «Бедринцю кореневища». 
Фітохімічні дослідження

\section{Phytochemical researches}

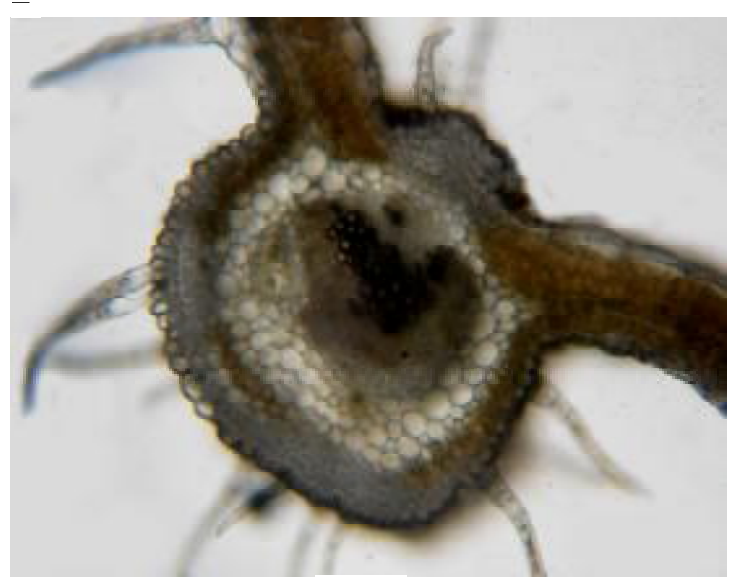

1

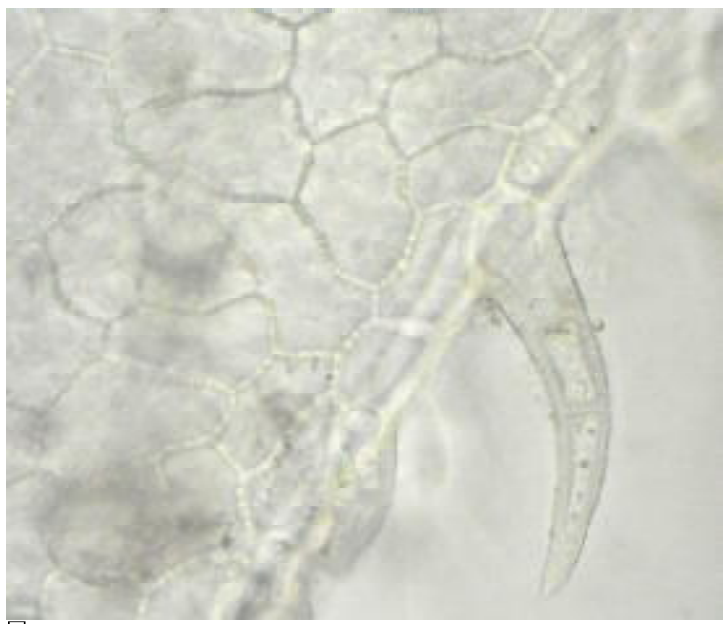

3

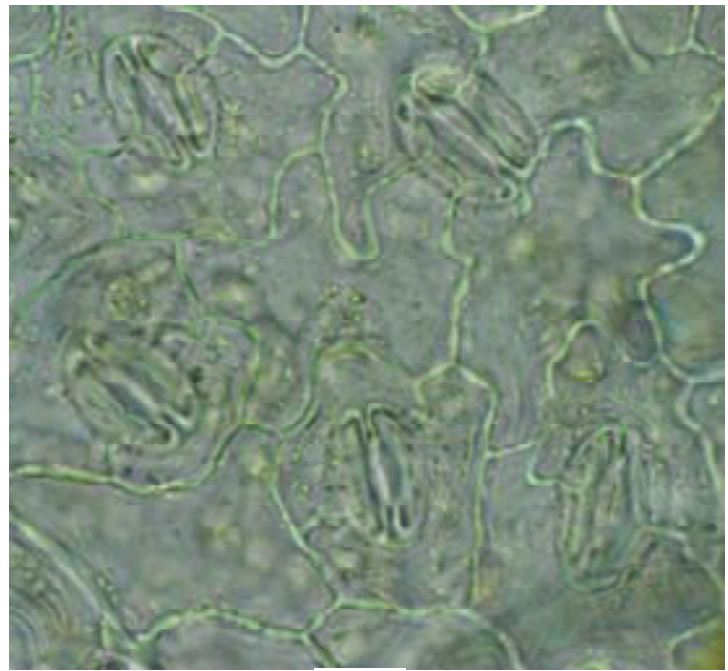

5

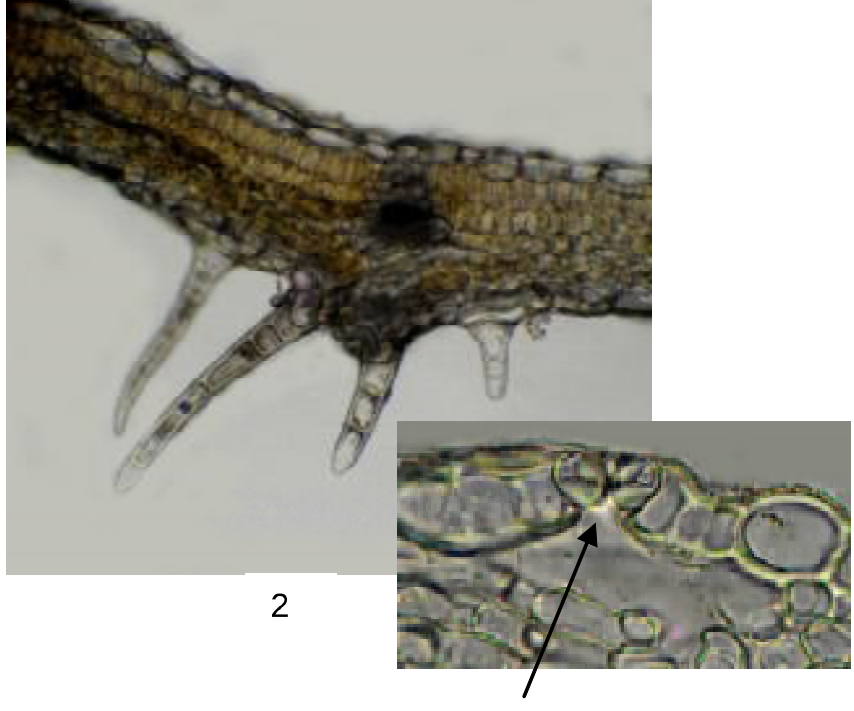

a

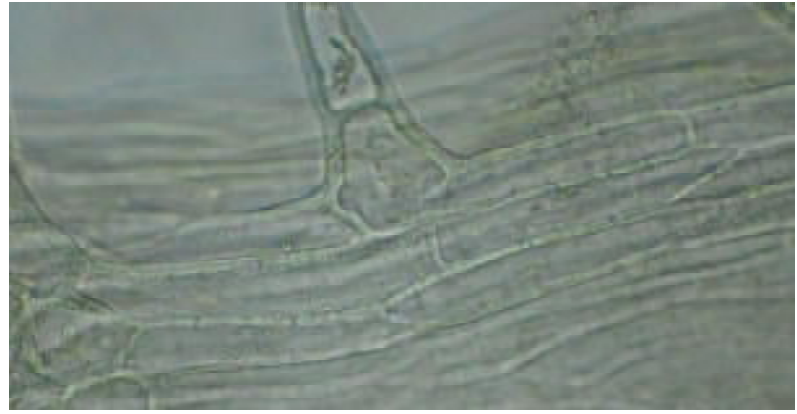

4

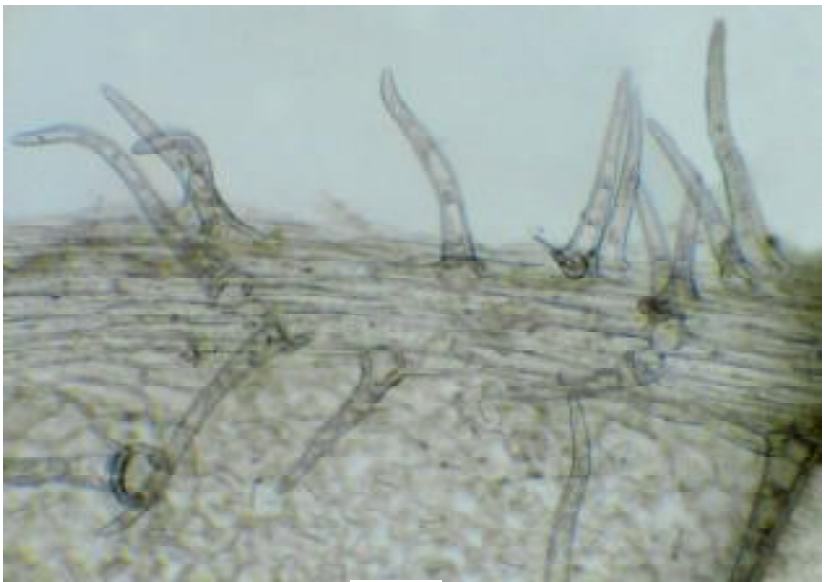

6

Рис. 4. Листок бедренцю: 1 - головна жилка, 2 - поперечний розріз листка, a - продих, 3 - верхня епідерма, 4 - епідерма над жилкою, 5 - нижня епідерма, 6 - опушення над жилкою.

ISSN 2312-0967. Фармацевтичний часопис. 2015. № 2 


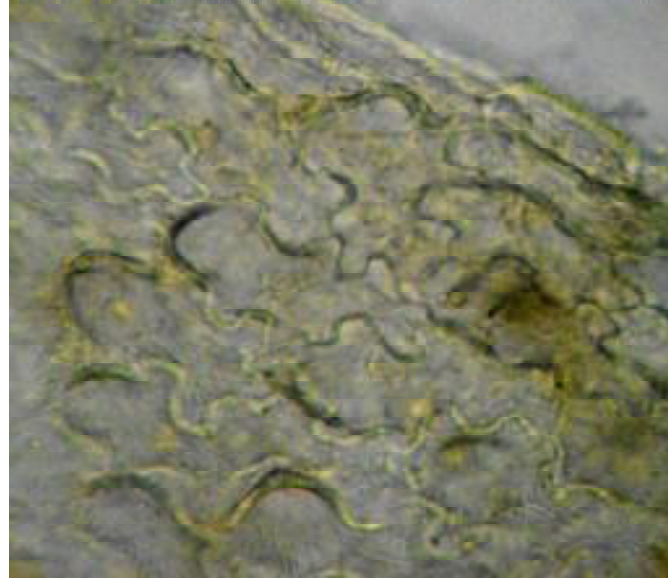

1

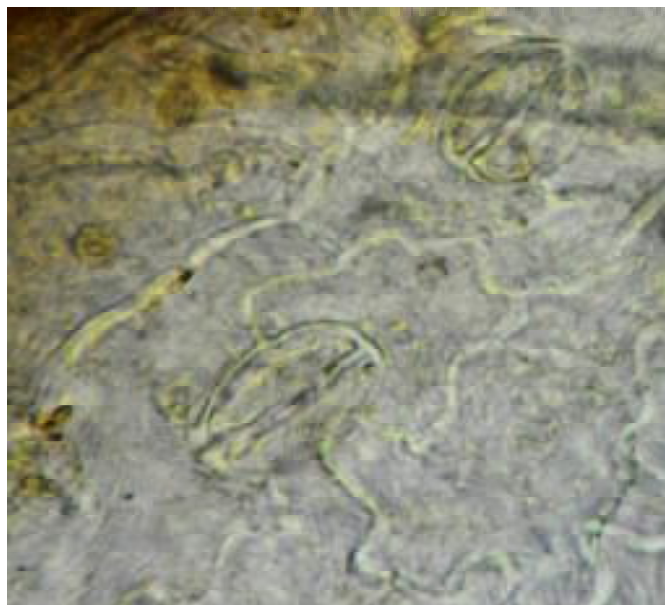

3

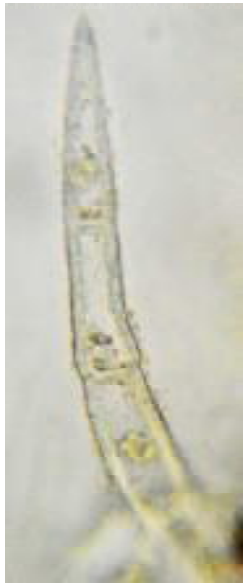

$5 a$

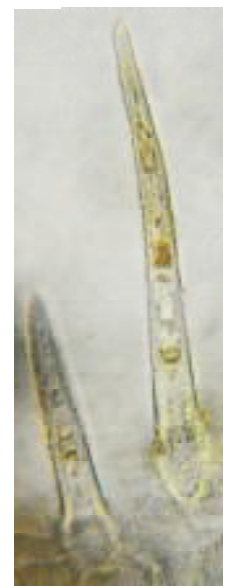

56

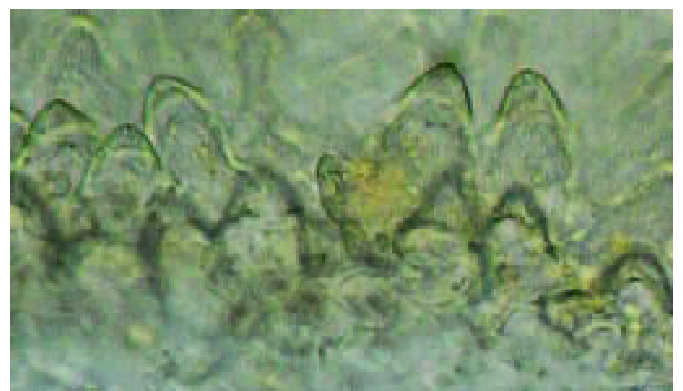

2

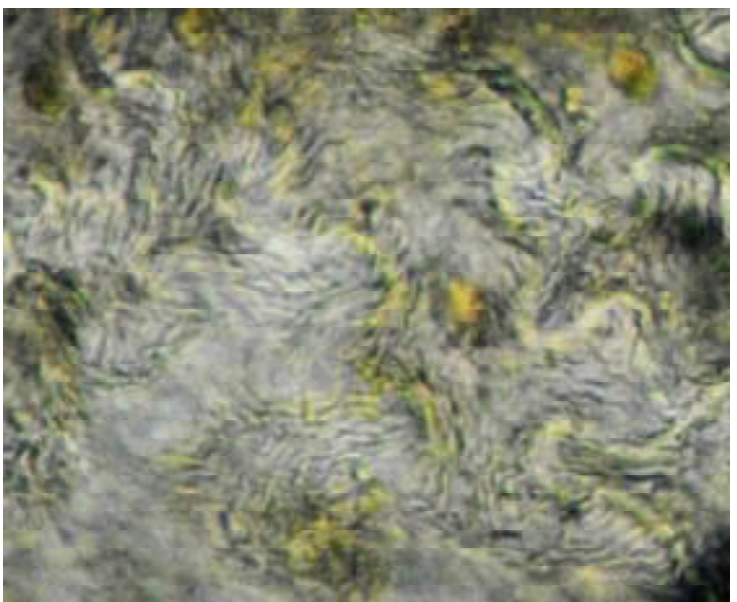

4

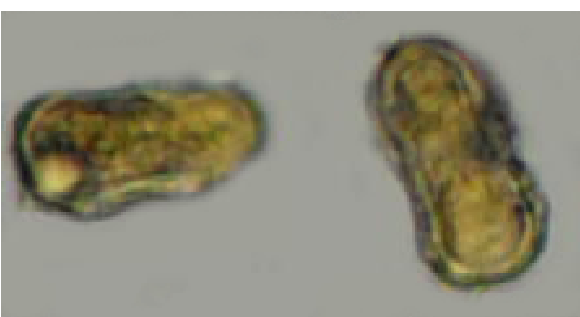

6

Рис. 5. Пелюстка: 1 - верхня епідерма, 2 - сосочкоподібні вирости, 3 - нижня епідерма, 4 - складчаста кутикула, 5 - трихоми: a - 3-клітинний волосок, б - 1- та 4-клітинний волосок, 6 - пилок. 


\section{Література}

1. Определитель высших растений Украины / и др.]. - М. : Изд-во МГУ, 2004. - 312 с.

Д. Н. Доброчаева, М. И. Котов, Ю. Н. Прокудин и др. -

К. : Наук. думка, 1987. - 548 с.

2. Марчишин С. М. Лікарські рослини Тернопільщини /

5. Травник [Електронний ресурс] // Бедринець ломикаменевий. - Режим доступу до інф.: http://dna.com. ua/3971-bedrinec-lomikameneviy.htmІФармакогнозия.

С. М. Марчишин, Н. О. Сушко. - Тернопіль : Навчальна книга - Богдан, 2007. - С. 48-50.

3. 100 самых популярных лечебных растений / сост. :

В. Рыжская. - Донецк : Мультипресс, 2010. - 287 с. 6. Атлас: учебное пособие: в 3-х томах. - М. : ГЭОТАРМедицина, 2010. - Т 3. - 488 с. : ил.

7. Фурст Г. П. Методы анатомо-гистохимического исследования растительных тканей / Г. П. Фурст. - М. :

4. Справочник по ботанической микротехнике. Основы и методы / [Р. П. Барыкина, Т. Д. Веселова, А. Г. Девятови Наука, 1979. - 154 с.

\section{МОРФОЛОГО-АНАТОМИЧЕСКОЕ ИССЛЕДОВАНИЕ БЕДРЕНЦА КАМНЕЛОМКОВОГО (РIMPINELLА SAXIFRAGA L.)}

\section{С. М. Марчишин, Т. М. Гонтовая, Э. А. Панасюк}

Тернопольский государственный медицинский университет имени И. Я. Горбачевского Национальный фрармацевтический университет, Харьков

Резюме: проведено морфолого-анатомическое исследование травы и корневищ бедренца камнеломкового. Для идентификации сырья установлены основные макро- и микроскопические признаки.

Ключевые слова: бедренец камнеломковый, трава, корневища, макро- и микроскопические признаки.

\section{MORPHOLOGICAL-ANATOMICAL INVESTIGATION OF BURNET SAXIFRAGE (PIMPINELLA SAXIFRAGA L.)}

\section{S. M. Marchyshyn, T. M. Hontova, E. A. Panasiuk}

Ternopil State Medical University by I. Ya. Horbachevsky National University of Pharmacy, Kharkiv

Summary: the investigation of the herb and rhizome of burnet saxifrage was conducted. The main macro and microscopic features were set for the identification of the raw material.

Key words: burnet saxifrage, herb, rhizome, macro- and microscopic features.

Отримано 11.03.2015 